\title{
InSAR Time Series Analysis of L-Band Data for Understanding Tropical Peatland Degradation and Restoration
}

\author{
Zhiwei Zhou ${ }^{1,2, * \mathbb{D}}$, Zhenhong Li $^{3}\left(\mathbb{D}\right.$, Susan Waldron ${ }^{2}$ and Akiko Tanaka 4 (D) \\ 1 State Key Laboratory of Geodesy and Earth's Dynamics, Institute of Geodesy and Geophysics, Chinese \\ Academy of Sciences, Wuhan 430077, China \\ 2 School of Geographical and Earth Sciences, University of Glasgow, Glasgow G12 8QQ, UK; \\ Susan.Waldron@glasgow.ac.uk \\ 3 COMET, School of Engineering, Newcastle University, Newcastle Upon Tyne NE1 7RU, UK; \\ Zhenhong.Li@newcastle.ac.uk \\ 4 Geological Survey of Japan, National Institute of Advanced Industrial Science and Technology, \\ Tsukuba 305-8567, Japan; akiko-tanaka@aist.go.jp \\ * Correspondence: Zhiwei.Zhou@whigg.ac.cn; Tel.: +86-27-68881355
}

Received: 8 September 2019; Accepted: 31 October 2019; Published: 5 November 2019

check for updates

\begin{abstract}
In this study, satellite radar observations are employed to reveal spatiotemporal changes in ground surface height of peatlands that have, and have not, undergone restoration in Central Kalimantan, Indonesia. Our time series analysis of 26 scenes of Advanced Land Observation Satellite-1 (ALOS-1) Phased-Array L-band Synthetic-Aperture Radar (PALSAR) images acquired between 2006 and 2010 suggests that peatland restoration was positively affected by the construction time of dams - the earlier the dam was constructed, the more significant the restoration appears. The results also suggest that the dams resulted in an increase of ground water level, which in turn stopped peat losing height. For peatland areas without restoration, the peatland continuously lost peat height by up to $7.7 \mathrm{~cm} / \mathrm{yr}$. InSAR-derived peat height changes allow the investigation of restoration effects over a wide area and can also be used to indirectly assess the relative magnitude and spatial pattern of peatland damage caused by drainage and fires. Such an assessment can provide key information for guiding future restoration activities.
\end{abstract}

Keywords: peatland; subsidence; restoration monitoring; InSAR; time series analysis

\section{Introduction}

As one of the most important natural wetland ecosystems in the world, peatlands cover about $2-3 \%$ of the Earth's land surface and store 500 to $700 \mathrm{Gt}$ of carbon [1], nearly equal to the atmospheric carbon pool (750 Gt) [2]. Therefore, peatlands play an important role in the global carbon cycle [3,4]. In the tropics, peatlands cover around 40 million hectares (Mha) and accumulate around $90 \mathrm{Gt}$ of carbon, while more than $54 \%$ and $76 \%$ of this tropical peatland area and carbon storage occur in South-East Asia [5]. Although tropical peatlands are rich in carbon storage, land use changes, drainage, and recurrent fires have resulted in extensive peatland degradation in this region during the past 20 years [6,7]. From 1990 to 2010, the forest coverage of South-East Asia decreased from 268 million ha to 236 million ha (an average net loss of 1.6 million ha $\mathrm{yr}^{-1}, 0.6 \% \mathrm{yr}^{-1}$ ) [8], which results in a warmer, drier environment at local scale [9]. Drainage of peatlands causes peat oxidation and releases carbon into the atmosphere as $\mathrm{CO}_{2}$, which results in peat subsidence [10]. It is estimated that an additional drainage depth of $10 \mathrm{~cm}$ results in $0.9 \mathrm{~cm}$ peat subsidence and approximately $9 \mathrm{t} \mathrm{CO}_{2} \mathrm{ha}^{-1} \mathrm{yr}^{-1}$ emissions [11]. Another severe consequence of drainage is that peat becomes dry and susceptible to 
fires during dry seasons (typically from June to October). Fires are the most severe in long dry seasons, such as the 1997/98 El Niño Southern Oscillation (ENSO) event. It was reported that 0.12-0.15 Gt of carbon was emitted due to peat combustion from Central Kalimantan, Indonesia during the ENSO dry season of 1997 [12]. The total carbon released to atmosphere due to the above emission from peat combustion in Indonesia in 1997 was between 0.81 and $2.57 \mathrm{Gt}$, which is equivalent to $13-40 \%$ of the mean annual global carbon emission from fossil fuels of 2001 [12]. Therefore, the restoration of peat hydrology and conservation of tropical peatlands is critical in order to prevent peat oxidation, peat fires and mitigate excess $\mathrm{CO}_{2}$ emission [13-15]. For example, from 2004 to 2008, hydrological restoration commenced in Central Kalimantan (of the Mega-Rice project drained landscape) by building large dams $[15,16]$, and understanding the effectiveness of the restoration activity is important for guiding future restoration activities.

Interferometric Synthetic Aperture Radar (InSAR) measures surface displacements in the line of sight to the satellite by differencing the phase measurements between two complex radar images acquired at two epochs but with similar satellite geometries, and the resulting difference phase forms a new kind of image called an interferogram [17]. In the last two decades, InSAR has been proven to be a powerful tool for measuring the Earth's surface movements [18]. It can be accurate to a few millimeters, with high spatial resolution (pixels in the order of sub-meters to tens of meters) over a wide area (e.g., $100 \mathrm{~km} \times 100 \mathrm{~km}$ or even wider) [19].

The potential of InSAR to measure peat height changes has been explored [20-27]. For example, in 2011, using four scenes of European Remote Sensing (ERS, C-band) tandem pairs (1 day interval) from October 1997 to January 2000 and the four-pass (four SAR images) InSAR method, a subsidence rate of $2 \mathrm{~cm} /$ year was estimated for Central Kalimantan, Indonesia [21]. In another study, using two pairs of Sentinel-1A image, the first pair acquired in June 2015 and June 2016, and second pair in June 2016 and July 2017, subsidence and uplift signals are revealed by two-pass InSAR (D-InSAR) method in peatland of Pelalawan Regency, Riau, Indonesia [27]. The four-pass InSAR method only uses one pair of SAR images to detect the surface deformation; the other pair is used to generate topography information and then applied to remove the topographic phase contained in the first pair. Although C-band tandem pairs promise high coherence in tropic forest, coherence is low for a longer image acquisition interval (such as 35 days) in areas with high dense vegetation [28]. The temporal decorrelation likely makes it difficult to apply C-band SAR images in tropical peatlands area, comparison to L-band SAR images [28]. Because shorter wavelength (C-band) has weaker penetration capability than longer wavelength (L-band). This leads to C-band radar signals are primary reflected back from the tree canopy and only a few signals are returned from the trunk, while the situation is on the contrary for L-band. For both four-pass and two-pass InSAR method, the surface movement rate estimation is likely to be limited as well, because atmospheric effects, orbital ramps, and decorrelation effects are not mitigated by the methods [17]. In addition, no information on the surface movement history can be obtained as well.

To reduce the temporal decorrelation and various errors, InSAR time series algorithms are developed by using multitemporal SAR images since 2001, such as Permanent Scatterer InSAR $\left(\right.$ PSInSAR $^{\mathrm{TM}}$ ) [29], Small BAseline Subset (SBAS) [30], SqueenSAR ${ }^{\mathrm{TM}}$ [31]. For more details about the concept and procedure, please refer to Batuhan et al., [18], the paper provides good reviews on InSAR time series method. Different InSAR time series methods and datasets are applied in measuring peatlands surface change. Using Intermittent Small Baseline Subset (ISBAS) DInSAR algorithm, ERS C-band images (1992-2000) and Sentinel-1 C-band (2015-2016), Alshammari et al., [25] detected subsidence and uplift change over peatland areas in the northeast of Scotland, UK. Using 161 Sentinel-1 SAR (C-band) images and ISBAS method, Marshall et al., [24] also measured the deformation patterns of tropical peat swamp around Kuala Lumpur International Airport. Fiaschi et al., [32] detected uplift signal of up to $8.9 \mathrm{~mm} /$ year and subsidence signal of up to $-11.6 \mathrm{~mm} / \mathrm{year}$ in Irish peatlands by using 124 Sentinel-1A/B images acquired from 4 May 2015 to 1 March 2018 and PS-InSAR method. Although, $\mathrm{C}$-band shows potential in measuring peatlands surface motion, it is likely hard to extract sufficient number of PS points and provide good coverage, particularly over a tropical peatlands area [24]. 
So far, the application of L-band data and InSAR time series methods for understanding peatlands degradation and restoration in tropical zone is rarely documented in peer-reviewed scientific literature. Therefore, the main goal of this study was to employ ALOS-1 PALSAR L-band SAR images (free of charge) acquired between 2006 and 2010, and InSAR Time Series with Atmospheric Estimation Model (InSAR TS+AEM) method to investigate the spatial and temporal evolution of the peatland surface change in Central Kalimantan, Indonesia. Since latest ALOS-2 PALSAR data are commercial data ( 2200 USD for a standard archived Stripmap image), it restricts their use to many end users because of budget constraints. And then assess the effects of hydrological peatland restoration through the use of dams in the drainage systems, which is important knowledge for the planning of future restoration projects.

\section{Materials and Methods}

\subsection{The Study Area}

In 1996, the Indonesian Government initiated the One Million Hectare Mega Rice Project (MRP) in Central Kalimantan (Indonesia). The principal objective of the MRP was food (rice) production in the area between the Sabangau River in the west, the Kahayan and Kapuas Rivers in the south and the Barito River in the east (Figure 1). The area was divided into four blocks (A, B, C, and D) according to the rivers' boundaries (light blue curves) in the MRP project, and the city of Palangkaraya is located in the north of Block C [16]. Large-scale deforestation was initiated in January 1996 to prepare the land for rice paddies, which involved mostly clear-felling the peat swamp forest and evacuating a massive network of in excess of $4400 \mathrm{~km}$ of drainage channels across the deep peat domes; some drainage channels were up to $30 \mathrm{~m}$ wide and $10 \mathrm{~m}$ deep $[15,16,33]$.

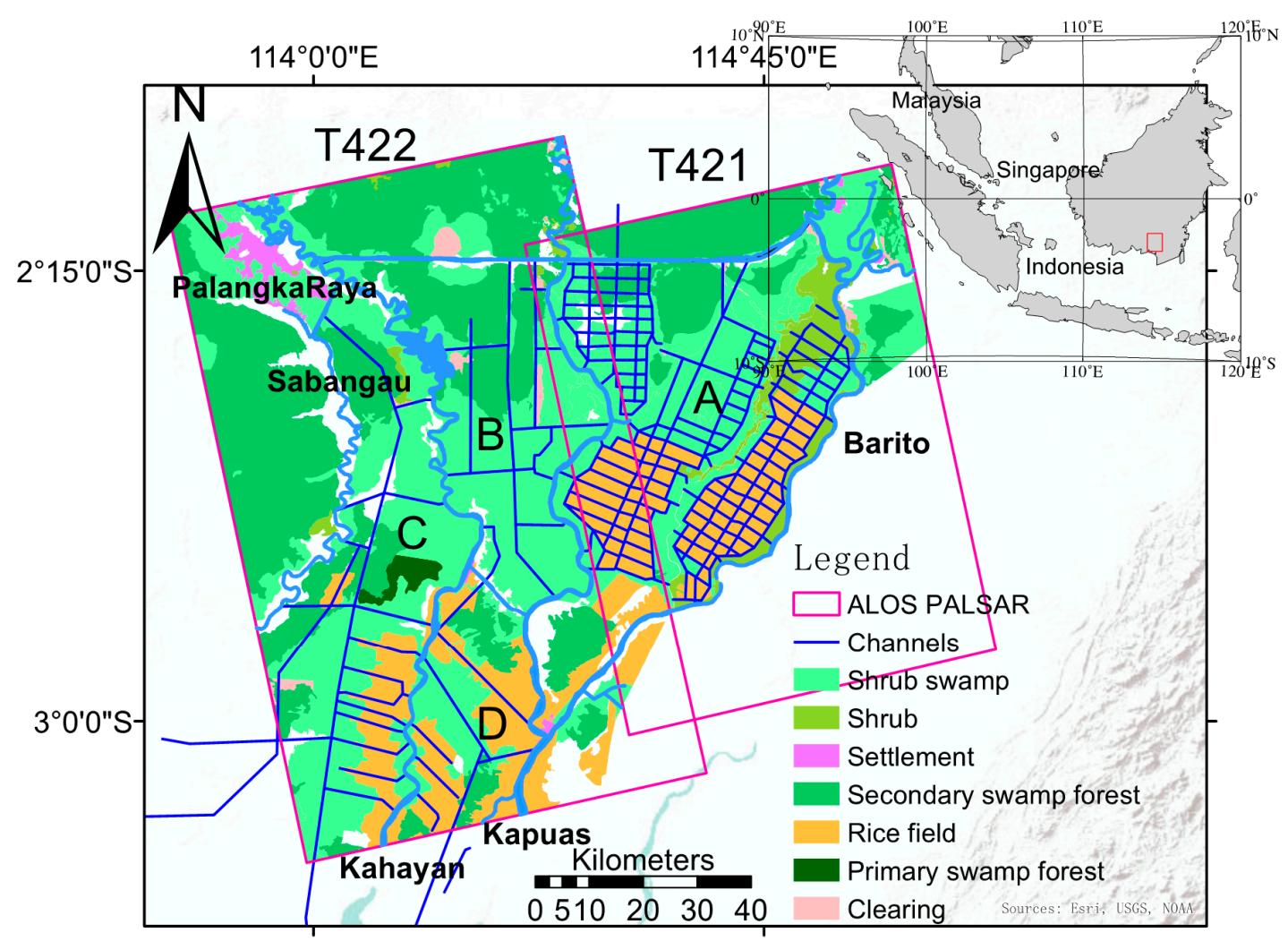

Figure 1. The location of this study area and distribution of land uses. Pink boxes denote the coverage of ALOS PALSAR images (Tracks 422 and 421). The four blocks of area (A-D) are indicated by light blue outlines. Land use information in this diagram is taken from Kementerian Kehutanan Republik Indonesia [34]. The red square in the top right corner is the location of this study area. 
In July 1999, the MRP was closed down because the area had been over-drained by the channels and unable to store water needed for agriculture irrigation. Consequently, the area was largely abandoned and is currently 'unproductive' and susceptible to flooding [35]. The drainage of the peatland caused by the network of extensive channels results in peat oxidation, subsidence, and regular outbreaks of large-scale fires [13,35,36]. Seven types of land cover dominate this area (Figure 1), i.e., shrub swamp, shrub, settlement, secondary swamp forest, rice field, primary swamp forest and clearing [34]. Most of the shrub swamp and rice field areas can be characterized as destroyed, abandoned and/or fire-damaged, and only a small part of the rice field area is still in use [14]. Note that the land cover data shown in Figure 1 was released in 2009 and an assumption was made in this study that there was no obvious land use change over the satellite observation period of 2006-2010.

In July 2004, hydrological restoration commenced in Block A under the CCFPI (Climate Change Forests and Peatlands in Indonesia) project, with the construction of five large drainage channel dams; 19 additional drainage channel dams were built in this area between 2007 and 2008, funded by the Central Kalimantan Peatland Project (CKPP). Between June and September 2005, seven dams were constructed in Block $C$ within the framework of the Academy of Finland funded KEYTROP (Keys for Securing Tropical Peat Carbon) and the EU-funded RESTORPEAT (Restoration of Tropical Peatland for Sustainable Management of Renewable Natural Resources) projects [15,16]. The dams in Block A are similar to those in Block C in terms of size and design [15,16,37].

\subsection{InSAR Interferometric Processing and Time Series Analysis}

In this study, two adjacent tracks of L-band (a wavelength of $23.6 \mathrm{~cm}$ ) ALOS-1 PALSAR images acquired between 2006 and 2010 were processed and analyzed (Table 1), covering a total area of $11,780 \mathrm{~km}^{2}$. L-band was used as this has a better penetration capability than shorter wavelength signals (such as C-band), and the ground and the trunks contribute to the signal and to avoid decorrelation caused by changes on the canopy. In this study, the coherence in heavy forest is generally low for interferograms with a perpendicular baseline (satellite separation) greater than $1000 \mathrm{~m}$ and/or a temporal baseline (i.e., time interval) longer than 1 year. To minimize the temporal decorrelation effects, only those image pairs with small baselines (i.e., perpendicular baseline $<1000 \mathrm{~m}$ and temporal baseline $<1$ year) were selected for interferometric processing and further analysis (Figure 2). All the interferograms were formed from raw radar images using the JPL/Caltech ROI_PAC (Version 3.1b) [38] with multi-look factor of 8 (in range direction) by 16 (in azimuth direction) to reduce the speckle noise, with a final resolution of about $80 \mathrm{~m}$ by $80 \mathrm{~m}$. The 3-arcsecond (about $90 \mathrm{~m}$ resolution) SRTM digital elevation model (DEM) [39] was used to remove topographic phase contribution. The interferograms were unwrapped using the SNAPHU algorithm [40] to obtain surface displacements in the satellite line of sight (LOS). A phase closure technique [41] was employed to identify major phase unwrapping errors that can then be manually corrected. The basic idea of the phase closure technique is that phase contributions behave in a conservative manner, i.e., $\varnothing_{A B}-\varnothing_{A C}-\varnothing_{B C}=0$, where $\varnothing_{A B}$ is the phase contribution of interferogram $\mathrm{AB}$ constructed from acquisitions $\mathrm{A}$ and $\mathrm{B}$. Using the phase closure technique, unwrapping errors were identified by summing around a loop and checking the residuals.

Table 1. ALOS images from Tracks 421 and 422 used in this study. Dates are given in Year-Month-Day (YYYYMMDD) format, and as number of days since the first image for each track. Perpendicular baselines (satellite separation) for Tracks 421 and 422 are relative to the reference dates that were chosen because of limited atmospheric effects on these two SAR images, assessed by checking all interferograms involved SAR images acquired on these dates.

\begin{tabular}{cccccccc}
\hline & \multicolumn{2}{c}{ T421 } & \multicolumn{3}{c}{ T422 } \\
\hline $\begin{array}{c}\text { Image } \\
\text { Number }\end{array}$ & Date & $\begin{array}{c}\text { Temporal } \\
\text { Baseline } \\
\text { (Days) }\end{array}$ & $\begin{array}{c}\text { Perpendicular } \\
\text { Baseline (m) }\end{array}$ & $\begin{array}{c}\text { Image } \\
\text { Number }\end{array}$ & Date & $\begin{array}{c}\text { Temporal } \\
\text { Baseline } \\
\text { (Days) }\end{array}$ & $\begin{array}{c}\text { Perpendicular } \\
\text { Baseline (m) }\end{array}$ \\
\hline 1 & 20061220 & 0 & 139.6 & 1 & 20070709 & 0 & 228.3 \\
\hline
\end{tabular}


Table 1. Cont

\begin{tabular}{cccccccc}
\hline \multicolumn{1}{c}{ Image } & Date & $\begin{array}{c}\text { Temporal } \\
\text { Bumber } \\
\text { (Days) }\end{array}$ & $\begin{array}{c}\text { Perpendicular } \\
\text { Baseline (m) }\end{array}$ & $\begin{array}{c}\text { Image } \\
\text { Number }\end{array}$ & Date & $\begin{array}{c}\text { Temporal } \\
\text { Baseline } \\
\text { (Days) }\end{array}$ & $\begin{array}{c}\text { Perpendicular } \\
\text { Baseline (m) }\end{array}$ \\
\hline 2 & 20070622 & 184 & 101.1 & 2 & 20070824 & 46 & 307.4 \\
\hline 3 & 20070807 & 230 & 208.5 & 3 & 20071009 & 92 & 129.4 \\
\hline 4 & 20070922 & 276 & -245.5 & 4 & 20080526 & 322 & -331.6 \\
\hline 5 & 20080207 & 414 & -16.1 & 5 & 20080711 & 368 & 0.0 \\
\hline 6 & 20080809 & 598 & 0.0 & 6 & 20080826 & 414 & -255.8 \\
\hline 7 & 20080924 & 644 & 494.1 & 7 & 20081011 & 460 & 471.2 \\
\hline 8 & 20081109 & 690 & 444.7 & 8 & 20090714 & 736 & 638.1 \\
\hline 9 & 20090627 & 920 & 332.8 & 9 & 20090829 & 782 & 741.1 \\
\hline 10 & 20090812 & 966 & -27.9 & 10 & 20091014 & 828 & 396.0 \\
\hline 11 & 20091112 & 1058 & 87.5 & 11 & 20091129 & 874 & 266.3 \\
\hline 12 & 20100212 & 1150 & 234.9 & 12 & 20100301 & 966 & 136.9 \\
\hline & & & & 13 & 20100717 & 1104 & -45.7 \\
\hline
\end{tabular}

To determine whether a dam can effectively block a drainage system, one way is to study data collected during dry seasons when there is less surface water and the surface area would be less affected by flooding. This avoids the study area being flooded, a period when there is no coherence. Therefore, only 12 and 14 PALSAR images acquired during dry seasons between 20 December 2006 and 1 September 2010 were used in this study (Table 1), and 27 and 30 small baseline interferograms were generated from Tracks 421 and 422 respectively (Figure 2). Finally, these 57 interferograms were geocoded with the SRTM DEM with a pixel spacing of $\sim 90 \mathrm{~m}$ for further time series analysis.
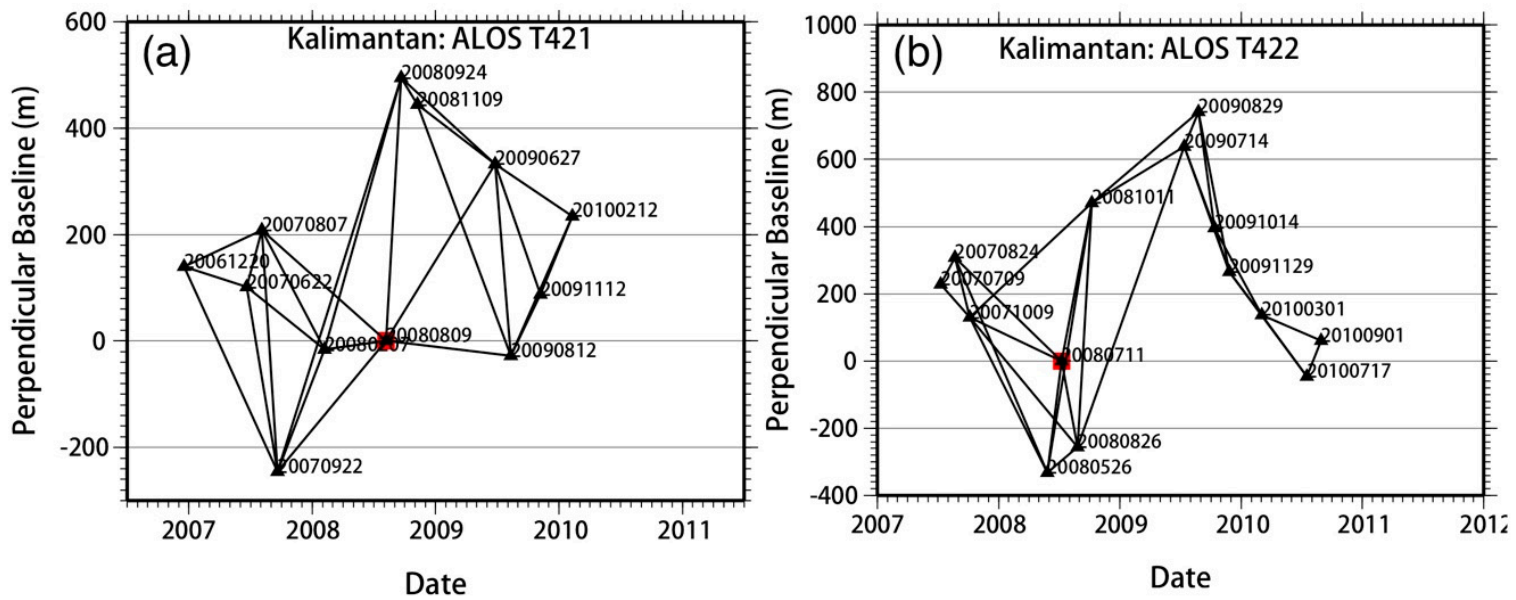

Figure 2. Small baseline interferograms generated from ALOS PALSAR Tracks 421 (a) and 422 (b) respectively. Each black triangle denotes one SAR image, and black solid lines between two black triangles represent interferograms. The red square marks the reference date for time series analysis.

The unwrapped phase consists of six terms: time invariant constant motion, non-linear surface motion, topographic errors, orbital ramps, atmospheric effects (atmospheric phase screen, APS) and noise. Several time series approaches have been developed to separate deformation signals (i.e., the first two terms) from the other four terms using multiple interferograms [29-31,42,43]. In this study, 
the InSAR TS+AEM [44] was used for time series analysis, which is based on the small baseline subset algorithm (e.g., [30]). In addition to full coherent pixels (i.e., those coherent pixels in every individual interferogram), partially coherent pixels (i.e., pixels with coherence greater than 0.3 in at least $50 \%$ independent interferograms) were also selected for time series analysis to increase the coverage of the final mean velocity maps $[45,46]$. The mean coherence of all the 27 interferograms from Track T421 is presented in Figure 3b. Comparing with the landcover map (Figure 1) visually, we can find that shrub swap area holds high coherence (higher than 0.5 ), the rice field area has moderate coherence (ranges from 0.3 to 0.5 ), while the primary and second swamp forest areas present low coherence (lower than 0.3 ). This suggests that the selected partially coherent points are expected in shrub swap and rice field areas, other than in primary and second swamp forest areas. For a given set of unwrapped interferograms, the topographic errors are correlated with the perpendicular baselines [17] and can be estimated and removed from the unwrapped phase. To remove orbit ramps, a network approach was employed to remove a best-fit plane from every interferogram [17]. The main difference between the remaining three terms is that the nonlinear displacements are correlated both in space and in time, the atmospheric contribution is correlated in space only, while the noise is spatially and temporally decorrelated in the unwrapped interferograms. Taking into account the spatial structure of atmospheric effects (correlated in space only) (e.g., the power-law process $[47,48]$ ), APS can be estimated using a temporarily linear velocity (TLV) model [44] and distinguished from the non-linear surface motion. The algorithm is applied iteratively until convergence is achieved $[44,49]$.

To assess the precision of the InSAR time series method used in this study, a correlation analysis between two mean height change rate maps from the two adjacent tracks was performed with data from their overlapping area. A correlation coefficient of 0.67 was obtained with an RMS difference of $0.7 \mathrm{~cm} / \mathrm{yr}$ (Figure 3c). Based on the assumption that the mean rate uncertainties in both tracks are identical, the RMS of the mean velocity is $0.49 \mathrm{~cm} / \mathrm{yr}$, suggesting the InSAR mean rate maps are reliable. Since the difference in incidence angle between the two tracks is small, its influence on the surface deformation projection on the line of sight can be neglected. Thus we combined data from both tracks to perform time series analysis using InSAR TS + AEM, and from this produced the final mean peat height change rate map and time series results. This was done with 26 dry-season SAR images acquired from 20 December 2006 to 1 September 2010, with the mid-timeline image acquired on 9 September 2008 chosen as the reference image, and a stable location at the city of Palangka Raya as the reference site. Within the overlapping area of the two tracks, the number of images included in the time series analysis is almost double, and hence the temporal resolution is increased significantly, providing a better estimate of the mean rate and displacement history. Outside the overlapping area, only one track of SAR images was used, and the InSAR results are almost identical to the previous time series results (i.e., one track included in time series only). The combined mean velocity map (rate of change of surface height) from both tracks is shown in Figure 3a, which will be used in the following analysis and discussions.

In areas with extensive channels and no restoration, four points (cleared (CL), fire scar (FS), rice field (RF) and secondary swamp forest (SF)) distributed within various land use categories were selected for further investigating peatland height change rates and history (Table 2, Figure 3a).

Table 2. Location and land use type of points selected in this study.

\begin{tabular}{cccc}
\hline Points & Longitude (Degrees) & Latitude (Degrees) & Land Use Type \\
\hline CL & 114.2395 & -2.2077 & Cleared \\
\hline FS & 114.3467 & -2.5248 & Fire scar (in shrub swamp) \\
\hline RF & 114.5186 & 2.6655 & Rice field \\
\hline SF & 114.4182 & -2.8581 & Secondary swamp forest \\
\hline
\end{tabular}




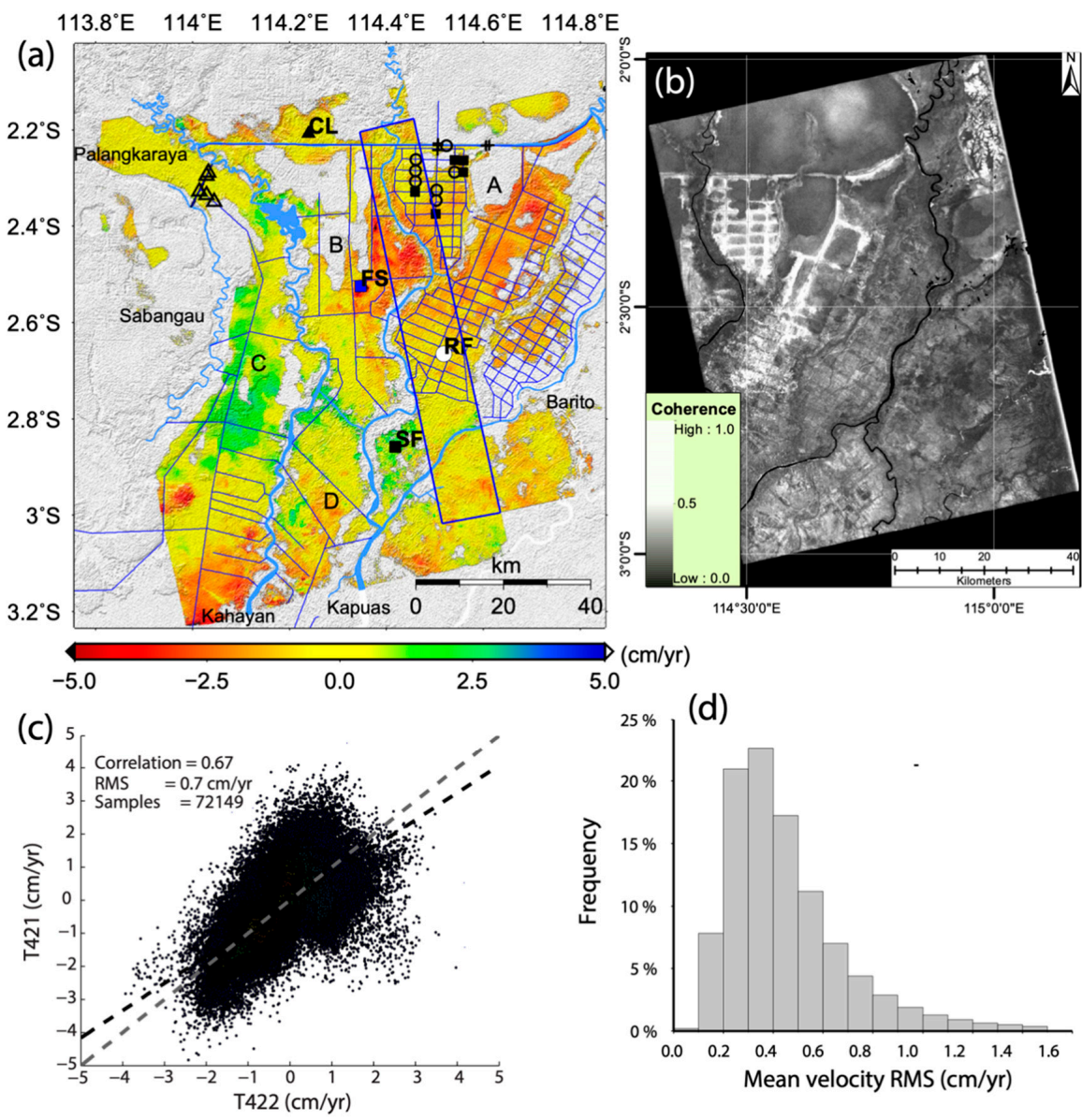

Figure 3. Mean height change rate map and correlation analyses: (a) mean velocity map between 2006 and 2010, light blue curves represent block boundaries and solid blue lines represent channels; negative value means subsidence and positive value means increase in height; dots CL, FS, RF and SF are four time series analysis sites, other triangles and square dots in Block $\mathrm{A}$ and $\mathrm{C}$ are dams; (b) The average coherence of 27 interferograms from Track T421, a pixel with coherence great than 0.3 presents a stable signal; (c) correlation of the mean velocities over the overlapping area between the two adjacent tracks 422 and 421 (Figure 1): the gray dash line indicates the 1:1 line and the black dash line indicates the best fitted line; and (d) the RMS histogram of the mean velocity map.

\section{Results}

\subsection{Mean Height Change Results of the Whole Study Area}

Figure 3a shows the final mean height change rate (mean velocity) map along line of sight. Note that the negative value means the surface is moving away from the satellite ('subsidence'), while the positive value means the surface is moving towards the satellite ('uplift'). The total number of partially coherent pixels is 859,118 (1,374,913 in total), covering $~ 62 \%$ of the study area, and approximately 73 points $/ \mathrm{km}^{2}$ at the case of $90 \mathrm{~m}$ resolution. With extensive channels areas in all blocks, subsidence signals can be observed clearly, the largest subsidence rate is more than $5 \mathrm{~cm} / \mathrm{yr}$. While the central part of Block C shows uplift signals. Between 2006 and 2010, the mean velocities for Block A, $\mathrm{B}, \mathrm{C}$ and $\mathrm{D}$ are $-1.1 \pm 1.0 \mathrm{~cm} / \mathrm{yr},-0.8 \pm 1.2 \mathrm{~cm} / \mathrm{yr}, 0.03 \pm 1.4 \mathrm{~cm} / \mathrm{yr}$ and $-0.3 \pm 1.2 \mathrm{~cm} / \mathrm{yr}$ respectively. In terms of area, $49 \%$ of the study area showed loss in surface height (less than $-0.7 \mathrm{~cm} / \mathrm{yr}$ ), $15 \%$ retained similar surface height (between $-0.7 \mathrm{~cm} / \mathrm{yr}$ and $0.7 \mathrm{~cm} / \mathrm{yr}$ ), and $37 \%$ increased in surface height (greater than $0.7 \mathrm{~cm} / \mathrm{yr}$ ). Figure $3 \mathrm{~d}$ shows the final root mean square (RMS) of the mean velocity with an average RMS of $0.45 \mathrm{~cm} / \mathrm{yr}$. 
The spatial pattern of the surface height changes appears to be associated with land use. No obvious surface height change can be observed in Palangkaraya city (NW corner of the study area) during the observation period, which is as would be expected. The drained shrub swamp area in Block B has the largest rate of decrease in surface heights. Much of this rice field areas in Blocks A, C and D show decrease patterns in surface heights. The cleared area has relatively small decreases in surface heights ranging from 0 to $2 \mathrm{~cm} / \mathrm{yr}$. In the center of Block $C$, signals in the secondary swamp forest area show increased surface heights during the observation period, with rates of up to $\sim 3 \mathrm{~cm} / \mathrm{yr}$.

\subsection{Peatland Height Changes in Area with Restoration}

The locations of the dams and their corresponding mean velocities are shown in Figure $4 a, b$ respectively. Because of the loss of coherence, Points A1-3 and A3-2 are not included in the change rate analysis. In Block A, dams are constructed in different year, completed in January 2005, May 2007 and June 2008 respectively, and their corresponding mean velocities are shown in Table 3 . The mean velocities in Block C are shown in Table 3. Note that the closer the mean velocity is to zero, it suggests the bigger impact of the dam construction on reducing the rate of surface height loss along the dams.
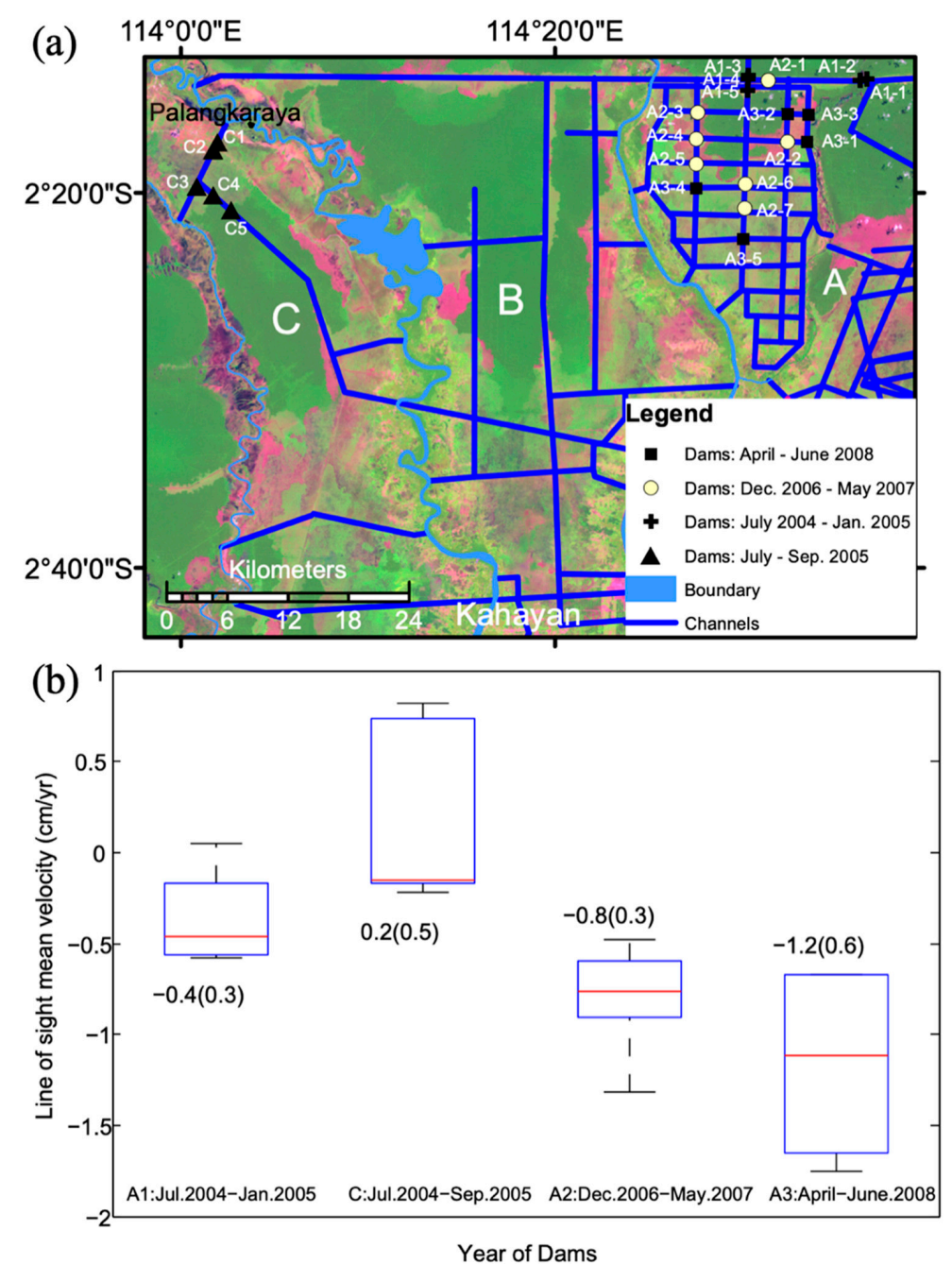

Figure 4. The location of Dams (a) and their corresponding mean velocity statistics analysis (b) in Blocks A and C. In (b), for each box, the central red line is the median, the edges of the box are the 25th and 75th percentiles, and whiskers represent the minimum and maximum values. Different construction dates of dams are denoted by different codes. Successful damming is considered to raise the ground water level and decrease the velocity of loss of surface heights. Each value corresponds to the mean velocity of 9 points within a $270 \mathrm{~m}$ by $270 \mathrm{~m}$ window. 
Table 3. Different types of dam and their corresponding mean velocities.

\begin{tabular}{cccccc}
\hline $\begin{array}{c}\text { Dam } \\
\text { Location }\end{array}$ & $\begin{array}{c}\text { Dam Completed } \\
\text { Date }\end{array}$ & $\begin{array}{c}\text { Minimum Mean } \\
\text { Velocities (cm/yr) }\end{array}$ & $\begin{array}{c}\text { Max Mean } \\
\text { Velocities (cm/yr) }\end{array}$ & $\begin{array}{c}\text { Mean } \\
(\mathbf{c m} / \mathbf{y r})\end{array}$ & $\begin{array}{c}\text { Std } \\
(\mathbf{c m} / \mathbf{y r})\end{array}$ \\
\hline A1 & January 2005 & -0.5 & -0.1 & 0.4 & 0.3 \\
\hline A2 & May 2007 & -1.4 & -0.5 & 0.8 & 0.3 \\
\hline A3 & June 2008 & -1.7 & -0.6 & -1.2 & 0.6 \\
\hline C & September 2005 & -0.25 & 0.75 & 0.2 & 0.5 \\
\hline
\end{tabular}

\subsection{Peatland Height Changes in Area without Restoration}

Figure 5 shows the evolution of peatland height at four points between 2006 and 2010. These four points are distributed in different land uses and have not undergone restoration. In Figure $5 \mathrm{a}$, Point CL located in the cleared area shows peat height to be decreasing at a mean rate of $-0.8 \mathrm{~cm} / \mathrm{yr}$. Point FS, located within a shrub swamp area (Figure $5 b$ ), had the greatest rate of decrease in surface height, by $17 \mathrm{~cm}$ during the dry seasons of 2007 to 2008, and $8 \mathrm{~cm}$ during 2008 to 2010, a total of $25 \mathrm{~cm}$ from 9 July 2007 to 1 September 2010. By checking Landsat images, fire scars can be found from the dry season of 2007 in this area, which may explain why surface lowering was greater between the dry seasons of 2007 to 2008 than during the following two years. Points in the rice field (RF) area exhibited relatively contestant rates of surface height decrease approximately $-1.0 \mathrm{~cm} / \mathrm{yr}$ (Figure $5 \mathrm{c}$ ). Point SF in the swamp forest shows an increase in surface height with a rate of $1.4 \mathrm{~cm} / \mathrm{yr}$. The signals of increasing surface height could be due to the accumulation of peat and /or water-logging changing peat structure (Figure $5 \mathrm{~d}$ ), as this area is not drained by extensive channels.
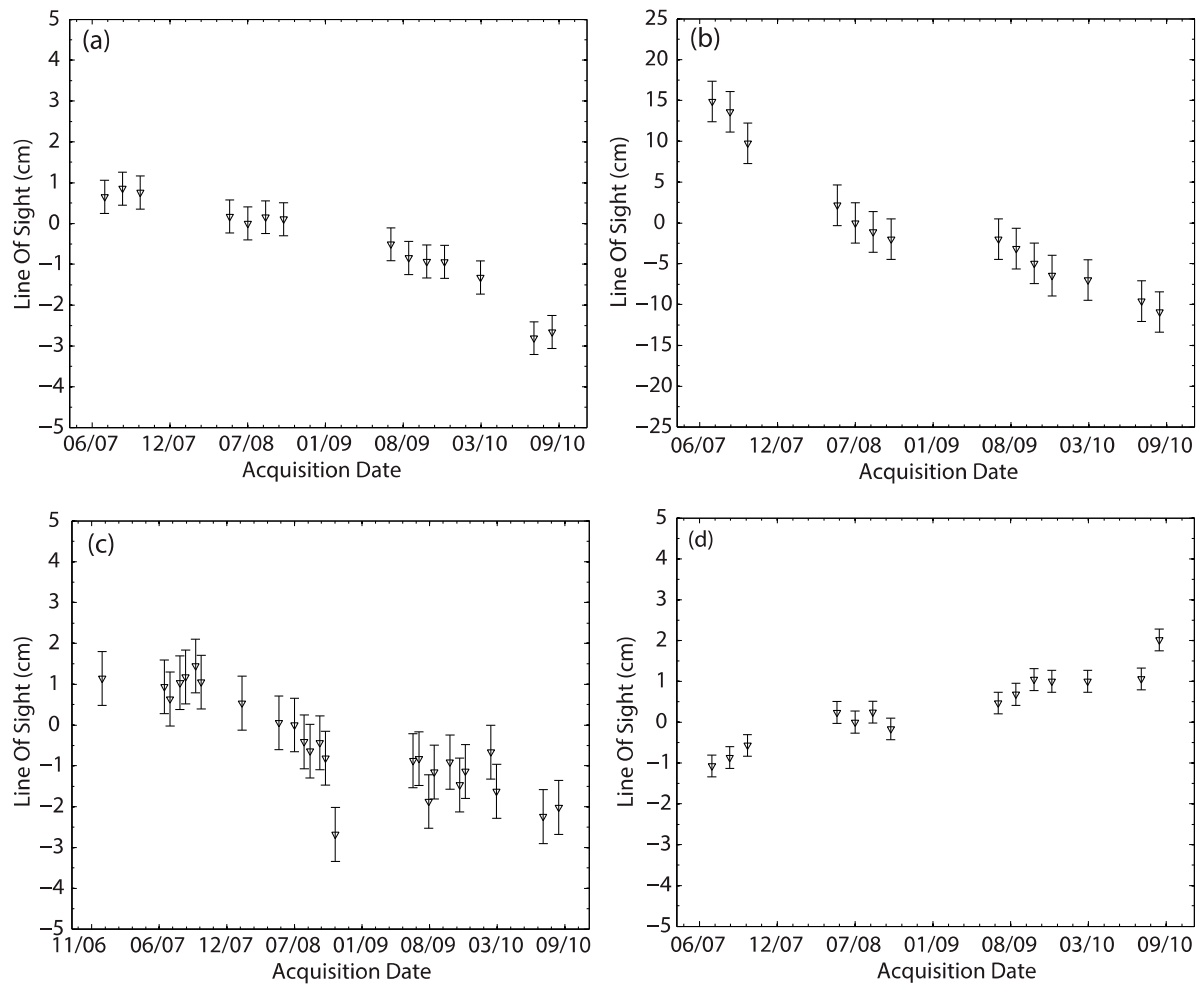

Figure 5. Time series of four points (CL, FS, RF and SF) located in areas with different land uses: (a) for CL point in cleared area, (b) for FS point in fire scar area, (c) for RF point in rice field area and (d) for SF point in secondary swamp forest area. Each point presents one SAR image acquisition date. Each value corresponds to the mean of points within a $270 \mathrm{~m}$ by $270 \mathrm{~m}$ window and the error bars represent the associated standard deviation. Note the scales in the Y-axis are not identical; the zero value corresponds to the reference image, which is acquired on 9th September 2008. 


\section{Discussions}

Although L-band data is used in this study, coherence is still lost in Block C. As show in Figure 3a, the InSAR results have good spatial coverage across the study area, covering various landscapes (Figure 1). By comparing the final valid pixel distribution in Figure 3a, the average coherence map of Track 421 in Figure 3b and land use map in Figure 1 visually, we observe that loss of coherent pixels is often associated with primary or secondary swamp forest, such as at the western part of Block C, the northern part of Block B, and a small area in the northern part of Block A. The loss of coherence is likely because the density of primary/second swamp forest is higher than $100 \mathrm{t} / \mathrm{ha}$ [50], where the radar signals are not able to penetrate it canopy of the forest, it returned radar signals are most likely from the canopy of the forest [51,52]. Therefore, temporal decorrelation occurs even over short time periods. While for forest density below $100 \mathrm{t} / \mathrm{ha}$, L-band radar signals can penetrate canopy and are predominantly reflected from the ground with strong double-bouncing contributions from the trunks [53]. Therefore, stable signals are expected from forest density below $100 \mathrm{t} /$ ha in our final results, such as signals from secondary swamp forest in the center of Block C. The eastern part of Block A also shows loss of coherent pixels, but this is because these areas are relatively-low and close to the river, still resulting in frequent summer flooding in this eastern part of Block A even in summer seasons [36].

L-band data would provide much better coverage than that of C-band. Using C-band data and intermittent coherent pixel algorithm in tropical peatlands, Marshall et al., [24] obtained data coverage over $94.35 \%$ of the study area by using a coherence threshold of 0.25 and a recurrence of $\sim 28 \%$ in all interferograms. However, the study also claims that if a coherent pixel is recurrent in each interferogram, only $25.35 \%$ of the study area would be covered by coherent pixels. In this study, a coherence threshold of 0.3 and a recurrence of 50\% in all interferograms strategy is applied, the final partially coherent pixels covers $62 \%$ of the study area. In addition, using C-band data and PS-InSAR method, only 333 stable PS points are found in $6 \mathrm{~km}^{2}$ boreal peatlands ( $\sim 56$ PS points $/ \mathrm{km}^{2}$ ), where vegetation is dominated by moss [32].Therefore less stable PS points per $\mathrm{km}^{2}$ are excepted for C-band in tropical peatlands.

The accuracy of the InSAR time series measurements in tropical peatlands is applicable to measure the peatland surface change. Without detailed ground data of this area, cross-validation is achieved by using the overlapping area data from the two independent adjacent tracks. A correlation coefficient of 0.67 was obtained with an RMS of the mean velocity is $0.49 \mathrm{~cm} / \mathrm{yr}$ implies the InSAR measurement has potential in measuring the tropical peatland height change. The InSAR time series methodology used in this study is also validated by using ground data in other studies, which provide an accuracy of 1.57 $\mathrm{cm} / \mathrm{yr}$ with a correlation efficient of 0.93 [54]. The accuracy obtained in these studies is also higher than that of ground measurements (e.g., perforated PVC tube inserted vertically in peatlands) [55]. Therefore, InSAR time series and L-band data could be a valuable tool in mapping magnitude and spatial pattern of peatland surface change.

Restoration requires time to take effect [14,15], implying that the earlier the dam is constructed, the more effective its presence will be. This is evidenced by the dams in Blocks A and C (Figure 4b). In Block A, dams completed in January 2005 appears to have more significant restoration effects compared to dams completed in May 2007 and June 2008 (both $p<0.05$, Table 4). Similar effects of successful rewetting were considered observed by investigating the backscatter changes of three PALSAR images acquired in August 2007, August 2008 and August 2009 respectively [15].

Table 4. Unpaired T-test for the mean velocities of the dams in Block A. Dams A1, A2, and A3 were completed in January 2005, May 2007, and June 2008, respectively.

\begin{tabular}{cccc}
\hline$p$ Value & A1 & A2 & A3 \\
\hline A1 & & 0.0415 & 0.0465 \\
\hline A2 & 0.0415 & & 0.1779 \\
\hline A3 & 0.0465 & 0.1779 & \\
\hline
\end{tabular}


Our SAR images were acquired from December 2006 to September 2010, nearly two years after the dam construction in Block C. The mean velocities of C1, C2 and C5 are close to zero, which means the areas near the dams are no longer losing height and thus loss of peat is slower. Increases in surface heights are observed in Points C3 and C4. The most plausible reason is that the ground water level increased in dry seasons and the peatland was rewetted, reducing loss of carbon through oxidation and, or, causing the peatland surface to rise or grow. Since the ALOS-1 PALSAR SAR images are only available after December 2006, we obtain the peat height change rates before the completion of the dam construction from a previous study [15]. By analyzing the backscatter changes of Envisat ASAR images acquired between 2004 and 2009, it was observed that backscatter increased in Block C after the completion of the dam construction in September 2005, implying that the peat soil moisture continuously increased with ground water level, even during the very prolonged dry season of 2006 [15]. Before the completion of the dam construction, a small decrease of the backscatter was observed between July 2004 and September 2005, implying that the peatland was continuously drained with a loss of carbon through oxidation, and resulted in losing peat height.

The swelling and shrinking of peat surface caused by changes in water availability (such as precipitation) had limited effects on the subsidence trend. In Block A (Figure 4b), dams were constructed during different periods, with the earliest being constructed in January 2005. The mean velocity of the dams constructed in January 2005 is smaller than the mean velocity of the dams constructed in May 2007, and the mean velocity of the dams constructed in May 2007 is smaller than the mean velocity of the dams constructed in June 2008. Figure 6a,b show LOS surface displacement time series for the A2 and A3 dams, and Figure 6c shows the monthly precipitation data derived from Tropical Rainfall measurement mission product (TRMM_3B43 V7) with a horizontal resolution of 0.25 degrees $\times 0.25$ degrees [56]. For all the dams completed in May 2007, the typical cumulative subsidence is approximately $4 \mathrm{~cm}$ between December 2006 and September 2010, and a clear subsidence trend can be observed in Figure 6a. For dams completed in June 2008, a similar subsidence trend can be observed between December 2006 and February 2010. The TRMM precipitation records show seasonal variations (Figure 6c), which cannot be observed in either of the LOS surface displacement time series. This suggests that (i) the swelling and shrinking of peat surface caused by changes in water availability (from precipitation) had limited effects on the subsidence trend, and (ii) the dams completed in May 2007 or in June 2008 had little effects on restoration during our SAR observation period, and a longer time is required to have effects on restoration.

Compared to surface height mapping with GPS or other methods, InSAR provides greater spatial extent in monitoring surface height changes, whilst keeping good precision. However, the InSAR TS + AEM algorithm has its disadvantages. For tropical peatland areas, there is often lack in sufficient number of L-band images within the same path and frame required for InSAR measurement. The lack of sufficient number of SAR images may make it difficult to detect adequate coherent pixels, and separate displacement signals from noises (e.g., the APS noise). For example, there are less than 20 L-band radar images acquired in this study area within the same path and frame by the current ALOS-2 satellite from 2014 to now. By comparison, there are more than 100 Sentinel-1A/B C-band radar images within the same path and frame over the same period. In addition, the use of L-band images could not detect low rate of motion in peatlands, as longer wavelengths tend to be less sensitive to small changes. 


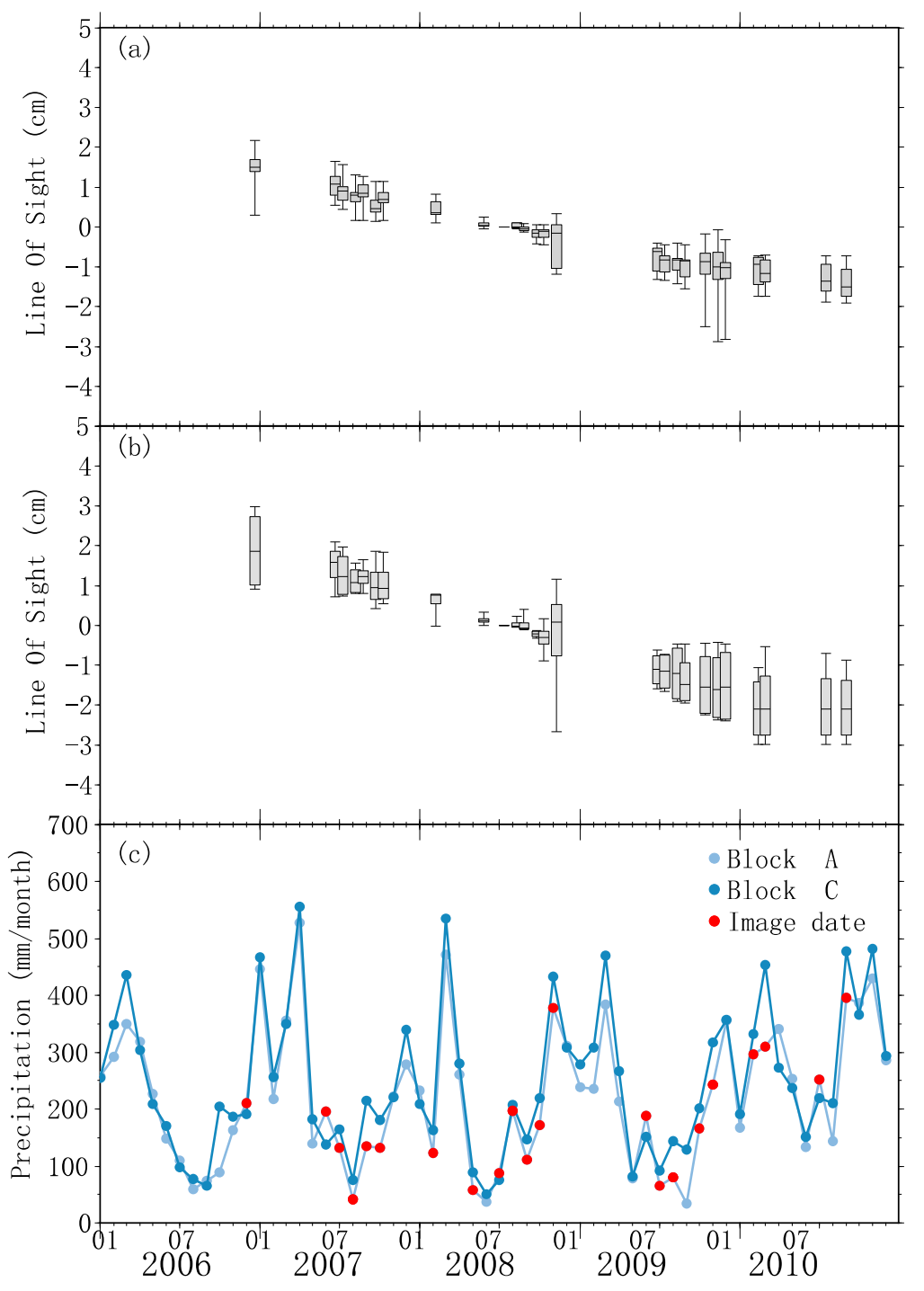

Figure 6. LOS surface displacement time series for (a) 7 dams constructed during the period from December 2006 to May 2007, (b) 4 dams constructed during the period from April to June 2008, and (c) the corresponding TRMM precipitation records (red dots). In Figure 6a,b, for each box, the central line is the median, the edges of the box are the 25 th and 75 th percentiles, and whiskers represent the minimum and maximum values. In Figure $6 c$, the blue dots present the TRMM record for Block $C$, while the light blue dots present for Black A. Note: (1) LOS surface displacements correspond to the mean LOS surface displacement of all the points within a $270 \mathrm{~m}$ by $270 \mathrm{~m}$ window, and (2) the reference date is 9 September 2008 .

\section{Conclusions}

Here we show that InSAR time series analysis of L-band data may be of considerable value in monitoring restoration effects in peatlands. Our analysis suggests that the restoration does have an impact and its effectiveness increases with construction time- the earlier the dam is constructed, the more significant the restoration is. The InSAR time series also provides insight in the likely relative magnitude and spatial pattern of damage to peatland caused by drainage and fires. To confirm the value of using InSAR time series, targeted fieldwork would help corroborate the InSAR understanding and also offer insight into why there are periods and areas of loss of coherence. With such security of understanding the community could proceed to using InSAR time series to make temporal and regional assessment of a landscape response to anthropogenic activity and guide future restoration activities. With this capacity InSAR offers a great advantage over field-based point observations by offering 
regional coverage, and provides a practical way to monitor peatland height changes continuously and globally, with the archived JERS/ALOS-1 dataset and the operational ALOS-2.

Author Contributions: Conceptualization, Z.Z., Z.L., and S.W.; data curation, Z.Z.; formal analysis, Z.Z.; funding acquisition, Z.L. and S.W.; investigation, Z.Z., Z.L., and S.W.; methodology, Z.Z. and Z.L.; project administration, Z.L. and S.W.; resources, Z.L., S.W., and A.T.; supervision, Z.L. and S.W.; validation, Z.Z.; visualization, Z.Z.; writing —original draft, Z.Z.; writing—review and editing, Z.L. and S.W.

Funding: Zhou was supported by the National Natural Science Foundation of China (Grant No. 41804017), by the Strategic Priority Research Program of the Chinese Academy of Sciences (Grant No. XDA19070104), by a China Scholarship Council (CSC) scholarship and the University of Glasgow. The work was supported the UK Natural Environment Research Council (NERC) through the Centre for the Observation and Modelling of Earthquakes, Volcanoes and Tectonics (COMET) and the GAS and LICS projects (Ref: NE/H001085/1 and NE/K010794/1 respectively) as well as the ESA-MOST DRAGON-3 projects (Ref: 10607 and 10665). METI (Japanese Ministry of Economy, Trade and Industry) and JAXA (Japan Aerospace Exploration Agency) retain ownership of the original ALOS PALSAR data used for this study, which were distributed by the Earth Remote Sensing Data Analysis Center.

Acknowledgments: Thanks to Stefano Tebaldini for reviewing this paper before submission.

Conflicts of Interest: The authors declare no conflict of interest.

\section{References}

1. Yu, Z.; Loisel, J.; Brosseau, D.P.; Beilman, D.W.; Hunt, S.J. Global peatland dynamics since the last glacial maximum. Geophys. Res. Lett. 2010, 37, L13402. [CrossRef]

2. Grace, J. Understanding and managing the global carbon cycle. J. Ecol. 2004, 92, 189-202. [CrossRef]

3. Page, S.E.; Baird, A.J. Peatlands and global change: Response and resilience. Annu. Rev. Environ. Resour. 2016, 41, 35-57. [CrossRef]

4. Jukka, M.; Aljosja, H.; Ronald, V.; Soo Chin, L.; Susan, E.P. From carbon sink to carbon source: Extensive peat oxidation in insular southeast asia since 1990. Environ. Res. Lett. 2017, 12, 024014.

5. Page, S.E.; Rieley, J.O.; Banks, C.J. Global and regional importance of the tropical peatland carbon pool. Glob. Chang. Biol. 2011, 17, 798-818. [CrossRef]

6. Dohong, A.; Aziz, A.A.; Dargusch, P. A review of the drivers of tropical peatland degradation in south-east asia. Land Use Policy 2017, 69, 349-360. [CrossRef]

7. Austin, K.G.; Schwantes, A.; Gu, Y.; Kasibhatla, P.S. What causes deforestation in indonesia? Environ. Res. Lett. 2019, 14, 024007. [CrossRef]

8. Stibig, H.J.; Achard, F.; Carboni, S.; Raši, R.; Miettinen, J. Change in tropical forest cover of southeast asia from 1990 to 2010. Biogeosciences 2014, 11, 247-258. [CrossRef]

9. Lawrence, D.; Vandecar, K. Effects of tropical deforestation on climate and agriculture. Nat. Clim. Chang. 2014, 5, 27. [CrossRef]

10. Wösten, J.H.M.; Ismail, A.B.; van Wijk, A.L.M. Peat subsidence and its practical implications: A case study in malaysia. Geoderma 1997, 78, 25-36. [CrossRef]

11. Couwenberg, J.; Dommain, R.; Joosten, H. Greenhouse gas fluxes from tropical peatlands in south-east asia. Glob. Chang. Biol. 2010, 16, 1715-1732. [CrossRef]

12. Page, S.; Siegert, F.; Rieley, J.O.; Boehm, H.-D.V.; Jaya, A.; Limin, S. The amount of carbon released from peat and forest fires in indonesia during 1997. Nature 2002, 420, 61-65. [CrossRef] [PubMed]

13. Sasha, A.; Cara, R.N.; James, A.; David, L.; An, C.; Kevin, L.E.; Finlayson, C.M.; Rudolf, S.d.G.; Jim, A.H.; Eric, S.H.; et al. Opportunities and challenges for ecological restoration within redd+. Restor. Ecol. 2011, 19, 683-689.

14. Wösten, J.H.M.; Clymans, E.; Page, S.E.; Rieley, J.O.; Limin, S.H. Peat-water interrelationships in a tropical peatland ecosystem in southeast asia. CATENA 2008, 73, 212-224. [CrossRef]

15. Jaenicke, J.; Englhart, S.; Siegert, F. Monitoring the effect of restoration measures in indonesian peatlands by radar satellite imagery. J. Environ. Manag. 2011, 92, 630-638. [CrossRef] [PubMed]

16. CKPP. Provisional Report of theCentral Kalimantan Peatland Project; CKPP Consortium: Palangka Raya, Indonesia, 2008; p. 70.

17. Hanssen, R.F. Radar Interferometry:Data Interpretation and Error Analysis; Kluwer Academic Plublishers: Dordrecht, The Netherland, 2001. 
18. Osmanoğlu, B.; Sunar, F.; Wdowinski, S.; Cabral-Cano, E. Time series analysis of insar data: Methods and trends. Isprs J. Photogramm. Remote Sens. 2016, 115, 90-102. [CrossRef]

19. Massonnet, D.; Feigl, K.L. Radar interferometry and its application to changes in the earth's surface. Rev. Geophys. 1998, 36, 441-500. [CrossRef]

20. Cigna, F.; Sowter, A.; Jordan, C.J.; Rawlins, B.G. ntermittent small baseline subset (ISBAS) monitoring of land covers unfavourable for conventional C-band InSAR: Proof-of-concept for peatland environments in North Wales, UK. In Proceedings of the SPIE-The International Society for Optical Engineering, Amsterdam, The Netherlands, 22 September 2014; pp. 924305-924306.

21. Dahdal, B. The Use of Interferometric Spaceborne Radar and GIS to Measure Peat Subsidence in Indonesia. Ph.D. Thesis, University of Leicester, Leicester, UK, 2011.

22. Zhou, Z.; Waldron, S.; Li, Z. Quantifying Changes in Land-Surface Height in Bioenergy Palm Oil Plantations (Sumatra) Using Insar Time Series; EGU: Vienna, Austria, 2013; Volume 15, p. 13128.

23. Zhou, Z. The Applications of Insar Time Series Analysis for Monitoring Long-Term Surface Change in Peatlands. Ph.D. Thesis, University of Glasgow, Glasgow, UK, 2013.

24. Marshall, C.; Large, D.J.; Athab, A.; Evers, S.L.; Sowter, A.; Marsh, S.; Sjögersten, S. Monitoring tropical peat related settlement using isbas insar, kuala lumpur international airport (klia). Eng. Geol. 2018, 244, 57-65. [CrossRef]

25. Alshammari, L.; Large, J.D.; Boyd, S.D.; Sowter, A.; Anderson, R.; Andersen, R.; Marsh, S. Long-term peatland condition assessment via surface motion monitoring using the isbas dinsar technique over the flow country, scotland. Remote Sens. 2018, 10, 1102-1125. [CrossRef]

26. Chaussard, E.; Hoyt, A.; Harvey, C. Bridging earth systems sciences with insar: From quantifying land subsidence to estimating the $\mathrm{CO} 2$ emissions associated with peatlands oxidation following deforestation in southeast asia. In AGU Fall Meeting Abstracts; AGU: Washington, DC, USA, 2018; p. G53B-07.

27. Susanti, R.D.; Anjasmara, I.M. Analysing peatland subsidence in pelalawan regency, riau using dinsar method. Iptek J. Proc. Ser. 2019, 2, 60-64. [CrossRef]

28. Meng, W.; Sandwell, D.T. Decorrelation of l-band and c-band interferometry over vegetated areas in california. Geosci. Remote Sens. IEEE Trans. 2010, 48, 2942-2952. [CrossRef]

29. Ferretti, A.; Prati, C.; Rocca, F. Permanent scatterers in sar interferometry. Geosci. Remote Sens. IEEE Trans. 2001, 39, 8-20. [CrossRef]

30. Berardino, P.; Fornaro, G.; Lanari, R.; Sansosti, E. A new algorithm for surface deformation monitoring based on small baseline differential sar interferograms. Geosci. Remote Sens. IEEE Trans. 2002, 40, 2375-2383. [CrossRef]

31. Ferretti, A.; Fumagalli, A.; Novali, F.; Prati, C.; Rocca, F.; Rucci, A. A new algorithm for processing interferometric data-stacks: Squeesar. Geosci. Remote Sens. IEEE Trans. 2011, 49, 1-11. [CrossRef]

32. Fiaschi, S.; Holohan, P.E.; Sheehy, M.; Floris, M. Ps-insar analysis of sentinel-1 data for detecting ground motion in temperate oceanic climate zones: A case study in the republic of ireland. Remote Sens. 2019, 11, 347-376. [CrossRef]

33. Jaenicke, J.; Wösten, H.; Budiman, A.; Siegert, F. Planning hydrological restoration of peatlands in indonesia to mitigate carbon dioxide emissions. Mitig Adapt. Strat. Glob. Chang. 2010, 15, 223-239. [CrossRef]

34. Kementerian Kehutanan Republik Indonesia. WebGIS Kehutanan. Available online: http://appgis.dephut.go. id/appgis/kml.aspx (accessed on 3 February 2012).

35. Page, S.; Hosciło, A.; Wösten, H.; Jauhiainen, J.; Silvius, M.; Rieley, J.; Ritzema, H.; Tansey, K.; Graham, L.; Vasander, H.; et al. Restoration ecology of lowland tropical peatlands in southeast asia: Current knowledge and future research directions. Ecosystems 2009, 12, 888-905. [CrossRef]

36. Hoekman, D.H. Monitoring Tropical Peat Swamp Deforestation and Hydrological Dynamics by ASAR and PALSAR; InTech: London, UK, 2009; pp. 257-275.

37. Hoekman, D.H. Satellite radar observation of tropical peat swamp forest as a tool for hydrological modelling and environmental protection. Aquat. Conserv. Mar. Freshw. Ecosyst. 2007, 17, 265-275. [CrossRef]

38. Rosen, P.A.; Hensley, S.; Peltzer, G.; Simons, M. Updated repeat orbit interferometry package released. Eos. Trans. Agu. 2004, 85, 47. [CrossRef]

39. Farr, T.G.; Rosen, P.A.; Caro, E.; Crippen, R.; Duren, R.; Hensley, S.; Kobrick, M.; Paller, M.; Rodriguez, E.; Roth, L.; et al. The shuttle radar topography mission. Rev. Geophys. 2007, 45, RG2004. [CrossRef] 
40. Chen, C.W.; Zebker, H.A. Phase unwrapping for large sar interferograms: Statistical segmentation and generalized network models. Geosci. Remote Sens. IEEE Trans. 2002, 40, 1709-1719. [CrossRef]

41. Biggs, J.; Wright, T.; Lu, Z.; Parsons, B. Multi-interferogram method for measuring interseismic deformation: Denali fault, alaska. Geophys. J. Int. 2007, 170, 1165-1179. [CrossRef]

42. Hooper, A.; Segall, P.; Zebker, H. Persistent scatterer interferometric synthetic aperture radar for crustal deformation analysis, with application to volcán alcedo, galápagos. J. Geophys. Res. 2007, 112, B07407. [CrossRef]

43. Doin, M.-P.; Guillaso, S.; Jolivet, R.; Lasserre, C.; Lodge, F.; Ducret, G.; Grandin, R. Presentation of the Small-Baseline NSBAS Processing Chain on a Case Example: The ETNA Deformation Monitoring from 2003 to 2010 Using Envisat Data; ESA: Paris, France, 2011; pp. 303-304.

44. Li, Z.; Fielding, E.J.; Cross, P. Integration of insar time-series analysis and water-vapor correction for mapping postseismic motion after the 2003 bam (iran) earthquake. Geosci. Remote Sens. IEEE Trans. 2009, 47, 3220-3230.

45. Zhang, L.; Ding, X.; Lu, Z. Ground settlement monitoring based on temporarily coherent points between two sar acquisitions. Isprs J. Photogramm. Remote Sens. 2011, 66, 146-152. [CrossRef]

46. Sowter, A.; Bateson, L.; Strange, P.; Ambrose, K.; Syafiudin, M.F. Dinsar estimation of land motion using intermittent coherence with application to the south derbyshire and leicestershire coalfields. Remote Sens. Lett. 2013, 4, 979-987. [CrossRef]

47. Li, Z.; Fielding, E.J.; Cross, P.; Muller, J.-P. Interferometric synthetic aperture radar atmospheric correction: Gps topography-dependent turbulence model. J. Geophys. Res. Solid Earth 2006, 111, B02404. [CrossRef]

48. Williams, S.; Bock, Y.; Fang, P. Integrated satellite interferometry: Tropospheric noise, gps estimates and implications for interferometric synthetic aperture radar products. J. Geophys. Res. Solid Earth 1998, 103, 27051-27067. [CrossRef]

49. Hammond, W.C.; Blewitt, G.; Li, Z.; Plag, H.P.; Kreemer, C. Contemporary uplift of the sierra nevada, western united states, from gps and insar measurements. Geology 2012, 40, 667-670. [CrossRef]

50. Treuhaft, R.N.; Gonçalves, F.G.; Drake, J.B.; Chapman, B.D.; dos Santos, J.R.; Dutra, L.V.; Graça, P.M.L.A.; Purcell, G.H. Biomass estimation in a tropical wet forest using fourier transforms of profiles from lidar or interferometric sar. Geophys. Res. Lett. 2010, 37, L23403. [CrossRef]

51. Imhoff, M.L. Radar backscatter/biomass saturation: Observations and implications for global biomass assessment. In Proceedings of the IGARSS'93-IEEE International Geoscience and Remote Sensing Symposium, Tokyo, Japan, 18-21 August 1993; pp. 43-45.

52. Luckman, A.; Baker, J.; Honzák, M.; Lucas, R. Tropical forest biomass density estimation using jers-1 sar: Seasonal variation, confidence limits, and application to image mosaics. Remote Sens. Environ. 1998, 63, 126-139. [CrossRef]

53. Bamler, R.; Hartl, P. Synthetic aperture radar interferometry. Inverse Probl. 1998, 14, 1-54. [CrossRef]

54. Zhou, W.; Li, S.; Zhou, Z.; Chang, X. Remote sensing of deformation of a high concrete-faced rockfill dam using insar: A study of the shuibuya dam, china. Remote Sens. 2016, 8, 255-269. [CrossRef]

55. Hooijer, A.; Page, S.; Jauhiainen, J.; Lee, W.A.; Lu, X.X.; Idris, A.; Anshari, G. Subsidence and carbon loss in drained tropical peatlands. Biogeosciences 2012, 9, 1053-1071. [CrossRef]

56. TRMM. InTropical Rainfall Measuring Mission. Available online: http://disc.gsfc.nasa.gov/datacollection/ TRMM_3B43_V7.shtml (accessed on 5 June 2015).

(C) 2019 by the authors. Licensee MDPI, Basel, Switzerland. This article is an open access article distributed under the terms and conditions of the Creative Commons Attribution (CC BY) license (http://creativecommons.org/licenses/by/4.0/). 